\title{
The Legal Subject in Althusser's Political Theory
}

\section{Roberto Buonamano}

The final publication is available at Springer via http://dx.doi.org/[10.1007/s10978-014-9139-3 ]

\begin{abstract}
There are three dominant conceptual developments in Althusser's work that suggest the significance of the subject. One is the perpetual work of ideology-its interpellation of individuals. The second is the primacy of the class struggle in relation to the state, and the consequential function of law and rights. The third is the materialism of the encounter as a process without subject. An examination of these three areas (in part, utilising a Foucauldian analysis of subjectivity and power relations) reveals the potentially and strategically important role of legal subjectivity in Althusser's theory of the political.
\end{abstract}

Keywords Althusser, Law, Subjectivity, State, Ideology, Foucault

The notion of the subject in Althusser's work is illusory. It is illusory in the sense that it appears to be an undefined (even undefinable) concept, while at the same time functionally significant, serving as a strategy to disguise the nature of the struggles in the socio-political field. Thus, Althusser's own uses of the concept betray feelings simultaneously of distrust and commitment. On the one hand, the reference to history-thus of the political - as a process without subject goes beyond the anti-humanism with which his early philosophy is often associated. It speaks positively of a condition for philosophical thought in which the political is not mediated by the subject-object dichotomy. On the other hand, the thesis on the role of ideology interpellating individuals as subjects promotes the urgency of analysing the structural conditions from which the ideological state apparatuses take effect in producing subjectivities. This assumes that the state of being a subject-in the dual sense of being subjected to and being the subject of - has a certain reality, an ontological presence, which is crucial to the understanding of the work of ideology in society.

It may be that this ambivalent relationship to subjectivity is meaningful in the context of Althusser's so-called methodological 'turn to the aleatory', in the sense that the singularity and unpredictability in the encounter establish, precisely in the negation of teleology, a possible space for emergent, resistant subjectivities, as Antonio Negri and others have suggested. In any case, if we are to take seriously this ambivalent approach to the subject - which is to say, that we do not merely relegate it to the contradiction between the ideological and 'aleatory' approaches to materialism, or indeed the assumed inconsistency in the thinking of an 'early' and 'late' Althusser-there is a need to account for Althusser's vision of the subject-in-being, in Foucauldian terms, the individual who is always in the process of formation. Scholars of Althusser's philosophical texts have identified certain, distinctive conceptual developments within his late works, among them the idea that the political, existing separately and in a variable relationship to social antagonisms, is self-instituting (or self-constituting). It is the fact that the political reproduces the relations of production, making possible the class struggle, that gives law (the power to legitimise norms and implement rights) a determinative function within the state machine - it marks the transformation of force into power. By the same token, the separation of the political sphere from that of social antagonism, and the process of the self-constitution of the state form, are theoretically 
continuous with the contingency of the state as reflecting constituted power. This not only places in contention the origin and stability of the political, but introduces a qualification in the relation of subjectivity, thus the relation of the subject to the state. If the individual is not reducible to the legal subject, the emancipatory role of rights that the discourse claims for itself is placed in contention. If the legal subject is only ever produced in the rupture of the political and the aleatory reality of the social, it becomes necessary to consider whether political resistance remains feasible only in the context of the abandonment of the juridically-constituted subject, and indeed whether such a condition is tenable.

\section{When the exterior implicates an interior: on the subjective double}

To understand the precise conditions for Althusser's dilemma, both that which he proposes in liberation of structural Marxism and that which he himself must escape to justify a non-metaphysical application of Marx's philosophy, we need to reconsider initially the terms of his interpretation of Marx's 'epistemological break'. The theoretical rupture between the humanist or anthropological philosophy of the young Marx and the radical theory of history and politics in the post 1844 writings invokes a methodological inversion as much as a reconstitution of philosophical praxis. Althusser's interpretation places great store in the scientificity ${ }^{1}$ of the new concepts associated with historical materialism: 'social formation, productive forces, relations of production, superstructure, ideologies, determination in the last instance by the economy, specific determination of the other levels, etc.' (Althusser 2005, p.193). Beyond the radical critique of humanist philosophy is the creation of a new discursive domain that illuminates a substantially different problematic - the situation of specific levels of human practice within the social structure, in place of the essentiality of man - which in turn depends upon a new tool - the scientific mapping of the historical conditions for determined processes. If Marxist theory is able to undermine the dual implication of the transcendental subject, namely, the empiricism of the subject and the idealism of human essence, it is because a distinct form of dialectics is at play: historical materialism reverses the question of establishing objective truth at the level of human thought or consciousness; because truth is already situated at the level of praxis, practice being the origin and criterion of all truth, the approach of scientific practice to the ensuing confrontation (of ideas and nature, consciousness and the real) 'entails recognition of the primacy of external reality over ideas or consciousness, which, in this practice, models itself on reality' (Althusser 1997a, pp. 251-252). It is relatively clear, then, that scientific practice cannot be reduced to self-consciousness, and that the fundamental task of philosophy as a theoretical practice ${ }^{2}$ is the 'actual critique of the illusions of any “consciousness”, denying the possibility of any subject of history' (Balibar 1993, p.6).

Within this methodological paradigm, subjectivity is viewed merely as a reflection of the necessary function of ideology; at the same time, ideology is conceived as a complex form, or rather, as giving form to a

\footnotetext{
${ }^{1}$ Such a reading in not without its concessions: postulating the 'theoretico-scientific' Marx that emerges from the errors of the Hegelian Marx raises its own historical questions about theory and objectivity; failing to attempt a genealogy of the preconditions for the new scientific method runs the risk of producing a new 'positivism' - see Derrida's comments in his interview on the topic of the relationship between Althusserianism and deconstruction (1993, p. 197).

2 'We can assert the primacy of practice theoretically by showing that all levels of social existence are the sites of distinct practices: economic practice, political practice, ideological practice, technical practice and scientific (or theoretical) practice' (Althusser and Balibar 2009, p. 63).
} 
complex, asymmetrical set of relations. At the structural level, Althusser's conception of ideology breaks free of teleological development: neither social processes nor sites of human agency can be considered to be the causes of ideology; instead they are simultaneously determined and determining functions that become meaningful in the context of ideological forces. Here, the notion of overdetermination becomes crucial, since, outside of a causal mode of analysis, it is the differential movement inherent in social processes-the changes, transformations, contradictions - that explains the 'material', constitutive foundation of ideas and consciousness as well as their field of operation. Nonetheless, we do encounter the difficulty of understanding how 'ideology' is conceived, particularly in light of Althusser's reference to ideology as an 'ideological concept' (1971). For ideology to be freed from all constraints associated with interiority (the ideas, beliefs, illusory perceptions), if it is, rather, to have an omnipresence that is implicated in and guides external reality, it effectively must be immanent to all social entities and relations, being neither cause nor product of the apparatuses. Let us examine the logic of this presupposition in Althusser's own terms.

In the first instance, ideology, 'endowed with a structure and a functioning such as to make it a nonhistorical reality', namely, immutable throughout history (paralleling the concept of the unconscious in Freud'ideology is external, exactly like the unconscious'), may be conceptualised only in relation to the existence of an actual, historical reality, the 'concrete history of concrete material individuals materially producing their existence'. 'Ideology in general'-Marx's imaginary assemblage, the pure, empty dream - is the ahistorical or omni-historical reality that remains present in the same form within 'the history of social formations containing social classes' (1971, pp. 160-161). In short, ideology is immanent, not transcendent. This leads to a particular understanding on the representative enterprise of ideology: 'Ideology represents the imaginary relationship of individuals to their real conditions of existence' (1971, p. 162). It cannot be the real conditions of existence that men represent to themselves in ideology, which would entail that ideology mirror (suggesting some consistency or direct association) those conditions; the true question is not one of causation, but of the rationale for the imaginary relation of individuals to the social relations governing their conditions of existence. There is, thus, an ontological distinction between the system of existing relations of production (and derivative social relations) and the imagined — necessarily distorted or illusory — relations represented by ideology.

In the second instance, Althusser's thesis that ideology has a material existence-if not seemingly paradoxical in suggesting the materiality of an ideal-is critical to the formulation of Ideological State Apparatuses and their practices being the realisation of an ideology, ideology always existing in the apparatuses and their practices. As Montag observes, this approach precludes the temporal and causal priority of ideology and 'eliminates any notion that ideology can exist external to its material form' $(1995$, p. 62). The argument that belief and consciousness do not pre-exist the behaviour and actions of individuals but are consubstantial with them implicates the exteriority of discourses as much as practices. The chain of materiality inscribed in the relation of the subject and the existence of the ideas of his belief is thus: 'his ideas are his material actions inserted into material practices governed by material rituals which are themselves defined by the material ideological apparatus from which derive the ideas of that subject' (Althusser, 1971, p. 168). Beyond the circularity of this equation there remains the problem of conceptualising the subjectivity inherent in the individual whose beliefs and actions are ineluctably bound up with the ideological apparatus; in what sense is this exterior meaningful where it does not stand in any relation to an interior? - in other words, what room is there for the expression of subjectivity given the immanence of ideology? 
The centrality of Althusser's thesis on the subject for his conceptualisation of ideology is attested by his own emphatic formula: 'the category of the subject is only constitutive of all ideology insofar as all ideology has the function (which defines it) of “constituting” concrete individuals as subjects' (1971, p. 171). There are a number of hypotheses that purport to explain this strange construction. One is that individuals are alwaysalready subjects, in the sense that they constantly and continuously practise the rituals of ideological recognition. This is so to the extent that even revolutionary activity is defined by and circumscribed within an ideological mentality. ${ }^{3}$ Indeed, there is more at stake here than the perpetual or interminable quality of subjection (the always); we must acknowledge that the interpellation of the subject is also a process without origin (the already). The production of subjectivity presupposes that individuals are necessarily abstract, the individual reflecting the institutions and practices of the society into which he is born and to which his existential needs are adapted. Further, being a subject is ultimately a matter of 'obviousness', in the sense of both transparency and immediacy. This, of course, gives rise to the aporia inherent in such a restricted conception of consciousness: inevitably, it serves a mediating role, while at the same time being confronted with the obviousness of the subject. The rejoinder argues, instead, that consciousness merely provides the individual with an awareness of his partaking of the incessant practice of ideological recognition, whereas knowledge of the mechanism of this recognition remains the object of our radicalised scientific method (see Althusser 1971, pp. 172-173).

It is not altogether clear whether the thesis on the interpellation of subjects can escape its logicogrammatical formulation, even with a reading sympathetic to the influence of Spinoza (which, of course, Althusser encourages). It would appear to be a solipsistic conclusion that the interpellation of the subject presupposes the existence of the subject, notwithstanding that the subject cannot be seen to have a defined birth or emergence. One possibility is to suggest that, rather than ideology transforming individuals into subjects, interpellation is itself the process of subjectivation. Močnik suggests, along this line of analysis, the existence of two interdependent mechanisms operative in the interpellation-subjectivity relation: subjectivation proper, being a purely formal symbolic mechanism with the same stereotypic structure; and identification, the imaginary relation concerned with the ideological conflict as an instance of class struggle (1993, p. 140). The double nature of the process (symbolic and imaginary) might work to ameliorate the contradiction in ideology, that of representing a reality of which it is itself part, but the concern with subjectivation being a reference to its own instance, namely, a pre-existing subject, remains live. In fact, we cannot assume that Althusser did not perceive this limitation. His resort to the concept of the 'Subject' in the example of religious ideology, the 'Unique, Absolute, Other Subject' in whose name individuals are interpellated as subjects, demonstrates the doubly specularly function of ideology, the 'duplication of the Subject into subjects and of the Subject itself into a subject-Subject' (1971, p. 180). Here, the Subject operates at the centre of an infinite number of individual subjectivations. The mirror-structure of ideology thereby attempts to resolve the paradox in the duality of the subject - the free subject that is author of his own actions, and at the same time, the subject that is subjected to a higher authority. The individual is interpellated as a (free) subject for the purpose of ensuring his free acceptance of his own subjection; in effect, the subject participates in its own subjectivity, in both senses.

\footnotetext{
${ }^{3}$ Thus, Althusser affirms, 'a subject is always an ideological subject. His ideology may change, shifting from the dominant ideology to a revolutionary ideology, but there will always be ideology, because ideology is the condition for the existence of individuals' (2006, p. 285).
} 
Importantly, the focus in this schema shifts from the interiority of individual subjectivity to the workings of the actual mechanism, the dual process of 'positive' and 'negative' subjectivation.

Formulated in this way, we are perhaps moving closer to a Foucauldian approach to subjectivity, even as Foucault's distrust of the term 'ideology' and critique of its uses in Marxist discourse might suggest a lack of empathy with the premise of ideology having a material existence. Already in The Archaeology of Knowledge Foucault proposes the task of examining the manifest construction and practical situation of knowledge, as a system of ideas, values and beliefs held together by distinct positivities or practices. Ideology would be merely one structural element of the conditions for the visibility of knowledge as an assemblage, a historical formation determined by discursive and non-discursive practices: 'The hold of ideology over scientific discourse and the ideological functioning of the sciences are not articulated at the level of their ideal structure...nor at the level of their technical use in society...nor at the level of the consciousness of the subjects that built it up; they are articulated where science is articulated upon knowledge' (Foucault 1972, p. 185). Moreover, in the analyses of specific institutions that lie at the intersection of relations of force constituting power and the formalised strata of knowledge, repression and ideology, far from being considered part of the struggle between forces, are treated as the mere effects of these struggles, since they necessarily operate within an established organisation of relations. Discipline, and the norm through which social space is rendered interdisciplinary and homogenising, is productive rather than repressive, producing and intensifying according to the logic of individualisation (Ewald 1992, p. 171). In short, power produces the reality that permits repression, and the truth that serves ideology. ${ }^{4}$ Thus, for Foucault, the fact that it is principally bodies and their thinking, rather than consciousness and interiority, which are at stake in the practices of subjection, suggests that one must necessarily look beyond the instruments of violence and ideology in order to understand the various (material) modalities of these mechanisms of subjectivation (Montag 1995, p.72). If we allow ourselves to interpret Althusser's thesis on the interpellated subject through the lens of Foucault's disciplinary analysis, as Montag (1995) proposes, the problem of the materiality of ideology could be reformulated in terms of the relation between the fictitious construct of reality created by the ideological representation of society and the specific technology of power (discipline) that individualises bodies, producing subjects.

There are sufficient convergences in the thinking of Althusser and Foucault to warrant our attention, especially with respect to the critique of humanism, ${ }^{5}$ and the material dependency and non-teleological nature of the subject, although Foucault's subject has a transformative-perpetually self-constitutive — character that is less obvious in Althusser's thesis. Foucault is quite explicit in declaring the problem of humanism as being its invention of a series of subjected sovereignties: ' the soul (ruling the body, but subjected to God), consciousness (sovereign in a context of judgment, but subjected to the necessities of truth), the individual (a titular control of

\footnotetext{
4 'The individual is no doubt the fictitious atom of an 'ideological' representation of society; but he is also a reality fabricated by this specific technology of power that I have called 'discipline'. We must cease once and for all to describe the effects of power in negative terms: it 'excludes', it 'represses', it 'censors', it 'abstracts', it 'masks', it 'conceals'. In fact, power produces; it produces reality; it produces domains of objects and rituals of truth. The individual and the knowledge that may be gained of him belong to this production' (Foucault 1979, p. 194).

${ }^{5}$ Though the intellectual relationship between Althusser and Foucault is one which largely must be constructed from their respective texts, Foucault did acknowledge Althusser's influence in the form of his re-examination of Marx's writings-in terms of a reliance upon a conception of human nature, of the subject, and of alienated man by certain Marxist theoriststhus, a shared methodological concern with 'the reevaluation of the theory of the subject'(Foucault 2001, p. 251).
} 
personal rights subjected to the laws of nature and society), basic freedom (sovereign within, but accepting the demands of an outside world and "aligned with destiny")' (1977, p. 221). It is in this sense-subjected sovereignties, or double subjectivation - that Delueze (1992) reads Foucault's notion of subjectivity as bound up with the visual motif of the fold. The 'foldings' (purposefully plural, for subjectivity is conceived as a multiplicity) refer to the doubling process intrinsic to thinking, the interiorisation of the outside. There are a couple of functional principles bound up with the idea of interiorisation. First, the folding-unfolding movement is inscribed in the subjectivation process, witnessing the transformation of the free man into subjection: it involves, on the one hand, being controlled and dependent on others via 'all the processes of individuation and modulation which power installs', and on the other, binding the subject to his own identity by a conscience or self-knowledge fashioned through the codes and techniques derived from the moral and human sciences (Deleuze 1992, p. 103). Thus, even the relation to oneself does not exist in a solitary and self-contained place independent of the outside (the institutional and the social); rather, it operates within the field of pre-existing relations, defined by them and in turn reconstituting them. The ethical relation is conceived as part of the broader ontological process - and, indeed, engaged through a new form of epistemology — of the constitution of the self as an object of knowledge, in the dual sense of the object of one's own reflection (the truth obligation) and the object of a scientific organisation of knowledge (Foucault 1997, p. 177). Second, the inside is necessarily coextensive with the outside, but an outside that is deeper and more distant—spatially and temporally - than any exterior. ${ }^{6}$ Or, reading with Heidegger, the intentionality of being, through which consciousness has free reign, gives way to the fold of Being (Deleuze 1992, p.110). Thinking, being neither innate nor acquired, can only come from the outside, thus the variables or conditions for thought are at the same time those concerned with the production of subjectivities. The topological relation of the folding of the outside establishes the limit for thought, albeit in a way that internalises external environments: to think is to be restricted to the 'present-time stratum', but through a past that is condensed within the inside (the 'present' subject is always a historically-constituted subject) and with the function to resist and re-think the present. In Deleuze's eloquent formula, 'Thought thinks its own history (the past), but in order to free itself from what it thinks (the present) and be able finally to "think otherwise" (the future)' (1992, p. 119). Folding thus has ramifications for political and ethical activity; it presents the possibility of new forms of struggle, as new forms subjectivity.

Althusser, in a different vein, also speaks of the mirrored or folded relationship between the internal and external, in this case with respect to the subject's interpellation through ideology. To be within ideologywhich is to say, to be the subject of ideological recognition, or 'hailing' - is to be the object of a ruse, the mere apparition or appearance of being outside of ideology, for it is the inherent effect of ideology to create the belief that one is not subject to ideological intervention. While scientific knowledge operates on the basis that ideology can be the object of analysis, thus that there must be a space external to ideology, 'ideology has no outside (for itself), but at the same time that it is nothing but outside (for science and reality)' (1971, p. 175). The 'speculary' structure of all ideology — the inside reflecting an outside that in fact is the entire reality-operates

\footnotetext{
${ }^{6}$ Deleuze speaks of the relation of the interior and exterior, in the context of the fold in the Baroque, in terms of an infinite receptivity and an infinite spontaneity. Their conciliation produces a new harmony, but on the premise that 'the expressed does not exist beyond its expressions' (Deleuze 1991, p. 243). As with the baroque model (in art and architecture), multiple subjectivities may be produced, infinite relations with oneself, but these modalities of folds are contained by the process of folding, which is to say, by their expressions.
} 
by way of a quadruple system of interpellation: individuals are interpellated as subjects; they thereby are subjected to the Subject; there is mutual (i.e. universal) recognition of subjects, within and among themselves; and, there is the absolute guarantee that this constitutes the way things are (1971, p. 181). This manifold process facilitates and regularises the concrete, material behaviour of individuals, such that subjects 'work by themselves', echoing the productive effects of individualising disciplinary control (whether in the context of criminality, labour or sexuality) discussed in Foucault's genealogical investigations. Indeed, there is no subjectivity without this (freely adopted) subjection. The sense of freedom is merely one of the effects of ideology, coded in institutions and social practices. Thus, subjectivity refers to the determination by ideological social relations, at once illusory—since ideology necessarily represents a distorted simulacrum of reality—and natural - interpellation is violently and abruptly imposed on individuals through their 'free consciousness'. 7

If Althusser's thesis appears to resolve the problem of the duality of subjectivity, with the subject being meaningful only in the sense of this abstract mechanism that qualifies the transformative capacity of the individual-subject, it is not without some logical circularity. We are reminded of Jacques Rancière's critique of Althuserrianism on the count of the speculative division between science (concepts) and ideology (words), being essentially a theory of representation. For Althusser, 'man' in Marx's ant-humanism is constrained within a class discourse in which he is merely an image reflecting and masking the conditions of bourgeois domination. 'The bourgeoisie's ideological power is thus described as the superposition of systems of representation: the system of judicial inscription transcribes trade relations; juridical ideology is reflected in the discourse of ' $m a n$ ' and 'subject'. The efficiency of power in ideology is nothing other than the efficiency of a representation of the conditions for the existence of that power' (2011, p. 95). There is the risk that ideology merely reiterates the 'interplay between essence and appearance', ${ }^{8}$ and that the subject reveals itself to be nothing other than the abstract entity that Marx's 'scientific' critique sought to undermine.

\section{The state and its apparatuses only have meaning from the point of view of the class struggle: the primacy of force}

As Althusser explains, what is truly at stake in the process of the mirror recognition of the Subject and the interpellation of individuals as subjects is the reproduction of the relations of production and those relations deriving from them. Moreover, it is the class nature of the ideologies, that they are realised in institutions, their rituals and their practices, that accounts for the methodological shift (from the abstract to the particular, the

\footnotetext{
${ }^{7}$ Althusser gives by way of example the case of the worker as 'subject'-by the time he arrives at his workplace he has already been subjected, voluntarily or involuntarily, to ideological forces that determine his decision to offer his services in exchange for the purchase of his labour-power: among other things, "the worker has been "formed" to conform to certain social norms that regulate behaviour: punctuality, efficiency, obedience, responsibility, family love and recognition of all forms of authority' (2006, p. 283).

${ }^{8}$ Indeed, the dialectics of essence/appearance, inside/outside, subject/object, call for an even more acute vigilance due to the indeterminate and infected nature of these oppositions. As Derrida remarks apropos the task of determining the effects of ideality, signification, meaning and reference in relation to the text: "The outside can always become an "object" in the polarity subject/object, or the reassuring reality of what is outside the text; and there is sometimes an "inside" that is as troubling as the outside may be reassuring. This is not to be overlooked in the critique of interiority and subjectivity' (1981, p. 67).
} 
general to the specific) in analysing ideology's role in social formations. ${ }^{9}$ The state form, then, is to be conceptualised in the context of the perpetual class struggle. It is characterised as a machine or apparatus precisely to denote its instrumental nature, and as the instrument of the dominant class it is necessarily separate not only from society but also from the class struggle itself, from which position it is able to dominate those it exploits and perpetuate the conditions of exploitation and oppression (Althusser 2006, p. 100). The state-and its politics, and the ideology that sustains it-is therefore separate and above the class struggle in a twofold sense. The political exists by virtue of, and indeed to conserve and maintain, the reproduction of the conditions of domination in its broadest connotation: not merely the reproduction of the conditions of 'social relations' and 'productive relations', but also the 'reproduction of the material conditions of the relations of production and exploitation' (Althusser 2006, p. 120). The autonomy of the political is ensured by the permanency of class conflict, simply because the political reproduces the antagonistic relations of production. Second, at the level of the organisation of power, the state-machine transforms force or the violence of class struggle-by which is meant the excess of the dominant class' force over the force of the dominated classes - into right, laws and norms (Althusser 2006, pp. 108-109). The embodiment of the state form, with its various agents and their nominated functions (administrative, monitoring, policing, juridical), serves no other purpose than this transformation of energy, and ultimately produces nothing except legal power. The logic of this transformative process is extrapolated in Althusser's interpretation of Machiavelli's thesis on the emergence of a principality: the new state to be formed, in order to become a national state, 'must be equipped with laws expressing the balance of forces in the class struggle between nobles and people', a struggle in which the Prince must take the side of the people, a struggle which is indispensable to the state's capacity to both survive and expand (Althusser 2000, p. 62). Viewed schematically, there are two moments in the constitution of a state. In the first, its foundation, the abstract formal moment of beginnings, the founder lays the foundation of the edifice by decreeing laws, thus becoming the lawgiver. The second is the "concrete, organic moment either of the penetration of the laws thus decreed into the antagonistic social classes, or of the production of laws by popular struggle against the nobles' (Althusser 2000, p. 65). In this latter stage, the mechanism of laws is the principal vehicle for the rooting of the prince's power in the people, and the latter is the absolute condition for the state's duration and power.

Does this analysis on the separate and self-instituting character of the political allow Althusser's thesis to escape the conventional philosophico-juridical discourse of sovereignty, a discourse that presupposes the existence of the subject of rights? To approach a response we must perhaps pose a more precise question: what has happened to the subject—where is the subject located, or how has it been displaced — with this separation of the political from the class struggle? At the very least, Althusser has entirely evaded, if not overturned, the contradictions in the relationship between state and society prevalent in traditional Marxist theory. ${ }^{10}$ The state's function is defined by, rather than in contest with, the reality of social antagonism. Where the origin of the state

${ }^{9}$ In one sense, such a shift is necessary in order to explain how an otherwise 'closed system of ideological production' opens the space for conflict and contradiction with respect to individual interpellations by ideological state apparatuses: 'A distinction must be made, then, between the general functioning of ideology that produces a particular notion of the individual subject, and the specific functioning of different ideologies that produce contradictions within and between subjects' (Grant 2005, p. 11).

${ }^{10}$ For Miguel Vatter (2004), this entails an inversion of the Marxist basis-superstructure schema on the basis that the 'struggle between classes is a factum of politics before being an economic or social datum'; see, also, Montag's (2004) response, in particular, his suspicion of the Marxist inversion or overcoming hypotheses. 
lies with the 'real' of the class struggle under the effects of the ideological state apparatuses, the concepts of base and superstructure are no longer meaningful, which is to say that the structural paradigm in which these terms take effect fails to account for the very existence of social antagonism and the relational dependencies through which it is preserved, namely, the primacy of the class struggle with respect to production and the primacy of the political with respect to the class struggle (see Vatter 2004, §15). ${ }^{11}$ Moreover, the reproduction of exploitative relations in the form of rights and laws establishes the legitimacy of the control of class conflict, thus of the special function of the state. If it is not possible to break from the circularity of the state, it is simply because the reproduction of the material and social conditions necessarily involves and implies the reproduction also of the state and its forms, while the state has the special function of maintaining and conserving the reproduction of existing class society (Althusser 2006, p. 125). In effect, Althusser's theory of the state eschews the concern for establishing right as the principal determinant of the political relation between subjects; instead, the state and its forms - including the ideological state apparatuses through which subjects are producedmerely legitimise the reproduction of the conditions of existence of the domination of the exploiting class. In this schema, law plays the part of a formal system of legality, a legalising power empty of any virtues of autonomy and positivism, and distinct from relations of production. The formal system of law, 'not despite but because of its formality and systematicity, depends upon a series of repressive and ideological supplements, that is, a locus of exteriority' (McGee 2012, p. 147).

Again, we can attain some clarity in understanding Althusser's challenge to structural Marxism by extending a connection to Foucault's thesis on security as an analytics of power. In his lectures titled 'security, territory, population' Foucault continues his genealogy of power by examining historically the mechanisms through which the biological fact of the human species becomes the object of a political strategy. For example, the Eighteenth century witnesses a re-orientation of the central concern for the political and economic management of society, under the imperative of controlling particular crises (such as the effects of scarcity from food shortages, or endemic-epidemic diseases), from the individual political and legal subject to the population, both as a natural phenomenon and a complex field for the application of governmental rationality. The population, as the object of economic-political analysis, no longer appears as the collection of individual wills tied by obedience to sovereign authority, but rather as 'a set of processes to be managed at the level and on the basis of what is natural in these processes' $(2009$, p. 70). The departure point for this politico-epistemic program is the given, the existential fact or naturalness of phenomena-phenomena which lend themselves to statistical analysis, distributive calculations, quantification and classification of variables, and so on-which thereby implicates the necessity and function of government; it is effectively a scientific discourse, one concerned with the dynamics in society, with its physical properties (as the physiocrats attest), as against the structural stasis of juridical discourse, with its conceptual paradigms - whether the contractual relationship of sovereign to subject, or the teleology of popular sovereignty (res publica). ${ }^{12}$ In a parallel discussion, Foucault argues that an

\footnotetext{
${ }^{11}$ Viewed in terms of the division between constituted and constituent power, it could be said that by reproducing the "exploitative relations in which the productive forces are exercised, the constituted power makes the "real" of social antagonism (dis-) appear as constituent power...the revolutionary power to begin the political "out of nothing", ex nihilo, as if it were self-grounding, auto-constitutive' (Vatter 2004, §17).

${ }^{12}$ This methodological agenda is clearly articulated throughout the lectures from 1975 on: 'Rather than looking at the three prerequisites of law, unity, and subject - which make sovereignty both the source of power and the basis of institutions-I think that we have to adopt the threefold point of view of the techniques, the heterogeneity of techniques, and the
} 
appreciation of the liberal moment in politics demands the reconceptualisation of the notion of 'freedom', from its metaphysical signification-the property of the ethical or political subject-to a technological signification - a legally-sanctioned instrument of power relations. Both in the sense of ideology and as a technique of government, 'freedom' is to be understood in the context of the mutations and transformations of technologies of power, as the correlative of the deployment of apparatuses of security. In fact, the functioning of an apparatus of security relies upon the existence of relative freedoms, certainly as they were conceived in the Eighteenth century: "no longer the exemptions and privileges attached to a person, but the possibility of movement, change of place, and processes of circulation of both people and things' (2009, pp. 48-49).

Both Althusser and Foucault situate politics within a matrix of forces, forces that have their own trajectories, whose logic defies the rational self-justification associated with conventional philosophical treatments of political power. These forces, or relations of power, are distinguished from both the forms (clusters) of political and economic subjection and the institutions and technologies of government. For Athusser, the separation of the state-machine and its special function-the reproduction of itself on the basis of its own effects - constitutes a system with complex mechanisms, perpetually masking its functions behind its apparatus, and vice versa, and its reproduction behind its interventions (Althusser 2006, p. 126). What is at stake in a philosophy of praxis is the unveiling of this masquerade, an attempt to understand the ensemble of the forms of class domination, its defence in and perpetuation through the pre-eminent mechanism of the state and its production of power (as right, political laws and ideological norms). In Foucault, we find a less structural analysis of this matrix. Relations of production and reproduction constitute merely particular types of relations (as with familial or sexual relations) through which mechanisms of power are exercised. It is less a matter of power being imposed upon such relations, for the purpose of acting on them, to modify or orient them in a particular direction for the sake of a certain objective, as the mechanisms of power being intrinsic to these relations, as both their effect and cause. The multiplicity of force relations are elements of the struggles and confrontations in society, and indeed one can take the permanency of these struggles (between individuals, groups, classes) as a principle from which to analyse power relations; however, at any given time and within a given field, the mechanisms of power intersect via 'lateral co-ordinations, hierarchical subordinations, isomomorphic correspondences, technical identities or analogies, and chain effects' (Foucault 2009, p. 2), and it is the singularity of these encounters — being neither ontological nor teleological — that should be investigated.

\section{A process without subject}

At this point it is worth considering, if only provisionally and schematically, Althusser's later concern with the 'materialism of the encounter'. The extent to which this concern represents a break with his previous interpretations of Marxist philosophy, and possibly a departure from Marxism itself, is of no special import for our current focus. More revealing is the interest in the historicism of an alternative (which is to say, non-

subjugation-effects that make technologies of domination the real fabric of both power relations and the great apparatuses of power' (Foucault 2003, p. 46). 
metaphysical) philosophical tradition, ${ }^{13}$ and, consequently, the potential conceptual openings for a novel critique of political and legal subjectivity. Utilising the terminology of Heidegger and Derrida in particular, Althusser defines the materialism of the encounter by the contrast with 'any idealism of consciousness or reason'; it is characterised by the primacy of positivity over negativity, the swerve over the straight trajectory, disorder over order, and by the negation of all teleology (whether rational, secular, moral, political or aesthetic). It is the 'materialism, not of a subject (be it God or the proletariat), but of a process, a process that has no subject, yet imposes on the subjects (individuals or others) which it dominates the order of its development, with no assignable end' (2006, p. 190). This enigmatic notion of a 'process without subject' is a crucial one for the task of a materialist philosophy, that of thinking the theoretical conditions of possibility for the resolution of existing contradictions-to situate different social practices under their ideologies, create theoretical schemas for overcoming contradiction, and guarantee the truth of this order through rational discourse (p. 287). The methodology utilised in Althusser's historicisation of the philosophy of the encounter is served by at least two key concepts: the conjuncture and the contingent. The conjuncture is the joining together of various elements, the facticity of events, from which any given form can emerge. It is not a transcendental structure, but the taking account of material conditions that present themselves at any given moment due to an infinite number of possible causes. Whether political, ideological or philosophical, the 'conjuncture is the facticity of the world that practice confronts, and practice is in turn possible only within the interstices of this facticity, since it can only intervene with the relations that constitute practice in the first place' (Morfino 2005, §52). The contingent refers to the aleatory character of the encounter-it is never prefigured insofar as the fact of its occurrence is underwritten by the possibility of its non-existence. The encounter emerges from the possibility of nothing-this is its radical instability - taking shape as a new regime of facts. There is no overarching determinant, neither origin nor end. Thus, Althusser speaks of the 'necessity of contingency' in a completely non-teleological sense. ${ }^{14}$

The reading of Machiavelli-achieved, in part, through establishing a theoretical continuity between Machiavelli's monarchist (The Prince) and republican (Discourses of Livy) texts - emphasises the problematic of the foundation without precedent, the 'primitive political accumulation', the concern with the preconditions of the constitution of a national state, thinking the fact to be accomplished (a new state under a new prince, its durability and longevity) rather than from the accomplished fact of absolute monarchies (Althusser 2000, p. 121). The subject-less process, as understood through Machiavelli, must account for the 'irreducible duality' between the subject of the political viewpoint (the people) and the subject of political force and practice (the Prince), a division that cannot be reconciled insofar as 'the people' does not constitute itself as a political force and is not transformed from a multitude into a governmental form. 'History must be made by the Prince from the viewpoint of the people; but the people is not yet "the subject" of history' (p. 27). One might interpret the

\footnotetext{
${ }^{13}$ Marx can now be read in the context of a philosophical milieu-tracing back to Epicurus and including thinkers as diverse as Machiavelli and Spinoza-preoccupied with developing thought of the provisional encounter, the aleatory and contingent, based on atomistic principles: "from Epicurus to Marx, there had always subsisted...the "discovery" of a profound tradition that sought its materialist anchorage in a philosophy of the encounter (and therefore in a more or less atomistic philosophy, the atom, in its "fall”, being the simplest figure of individuality)' (Althusser 2006, p. 188).

14 'That is, instead of thinking contingency as a modality of necessity, or an exception to it, we must think necessity as the becoming-necessary of the encounter of contingencies' (Althusser 2006, pp. 193-194).
} 
place or subject ' the people' as the perspective of social antagonism; ${ }^{15}$ its power lies precisely in the fact that the political viewpoint is not reduced to the constitution of political forms of government and any political practice (Vatter 2004, §26); this would permit the possibility of political agency on the part of the people. ${ }^{16}$ However, it has to be conceded that there is very little textual elucidation (the same could be said contextually, with regard to the opposition of political viewpoint and political practice) of the signification Althusser intends by the use of the term 'the people'. As a political concept, it can be understood in a differential way, as that part of a social whole that is distinct from another part or parts to which it is subordinate. In this sense, the people, as demos, constitutes an uprising against the regime rather than the regime itself; it is the subject of revolt, suggesting both, and at the same time, an immediate absolute and indivisible dignity that is without measure, and over time, the 'absolute value as an infinite opening that no quality, law, institution, or even identity can ever bring to a close'. Alternatively, 'the people' may be understood in an integral way, as the whole (the body) of social reality; the political sovereignty of the people would entail its self-constitution, preceding any political constitution. 'Here the subject-people is affirmed not as an actor or as a force but first of all as a substance: a reality that derives its existence and its movement only from itself' (Nancy 2010, pp. 38-39). Both meanings have some resonance with Althusser's characterisation of 'the people', but neither perfectly accounts for what Althusser considers to be crucial in Machiavelli's treatment of the political practice of the new prince: namely, that the state which the prince must lead is rooted in the people-it is a popular state, its popular character determining the political practice. The Prince, as the public face of the state, literally acts upon (first through acceptance, later to transform) the people's ideology to achieve his national and popular goals, assuming 'responsibility for the ideological effects of his own political practice'; thus, the representation of the figure of the Prince serves to mediate the ideological relation between Prince and people (Althusser 2000, pp. 97, 99). It is in this purely strategic sense that 'the people' is significant. We must avoid the speculative conclusion that a theory of popular sovereignty, of the people's exercise of political power in pursuance of the democratic form, is disguised in the Machiavellian readings. Instead, the people remains separate from the political—always as the founding moment of constituted power (the state), but never the constituent - the substance or reality rather than the actor, in Nancy's terminology.

What, then, is the place of subjectivity within the materialism of the encounter? If this question appears as a most urgent one arising from Althusser's later writings, it is nonetheless one to which he did not attend with any clarity and decisiveness. We can only venture to draw together distinct conceptual strands, all the while conscious of the fact that Althusser's work creates more openings than it develops coherent philosophical positions. The root of this problematic may be situated at a more fundamental, epistemological level. In posing the question, 'how is a singular individual also a universal?' Althusser refocuses his gaze upon subjectivityand the subject's situation in knowledge - in terms of the relation of appropriation that the human subject enters into with others. All processes of knowledge move from abstract generality to concrete singularity; the reality envisaged is that of a universal singularity (Althusser, 1997b, pp. 7-10). The possibility that the aleatory nature

\footnotetext{
${ }^{15}$ Althusser reads Machiavelli's invocation of the people (popolare) as an invocation of a struggle, the class struggle between the people and the nobles, in which the Prince must forge an alliance with the people (2000, p. 129).

${ }^{16}$ Vatter, invoking Derrida's (1994) spectral reading of Marx, goes so far as to suggest that the political agency of the people can be considered as deconstructive of forms of government, the return of the conflictual event haunting the emergence of political form $(2004 \S 28)$.
} 
of the encounter might establish a veritable space for collective subjectivity emerges from the scattered references to Spinoza's radical philosophy of subjectivity: the reversal of causes into ends; meaning as an 'eschataology of an imaginary meaning'; the critique of the illusion of subjectivity (that allows the individual to see himself as centre and master of the world, whereas he is entirely submitted to its determinations) - ideas from which may be extrapolated the hypothesis of individual subjectivity being derivative of 'social subjectivity' rather than its condition (Althusser 1997b, pp. 6-7). In Machiavelli's thinking, however, the notion of social subjectivity becomes a more sustained and directive principle of political practice. It may be that the true contingency with respect to the encounter, thus with respect to the form of its effects (the state), is its potential revocability (the return to the beginning), what Vatter (2004, §43-44) refers to as the 'sovereign indifference', the people's indifference to the state and its project of government, thus the ability to overturn the accomplished fact, or return to the state of the encounter - this would be the only true source of the people's power.

\section{The Legal Subject}

The fact that the dominant class can only endure as a state through the transformation of its power based on violence to a power based on consent assumes, as we have already noted, the existence of free subjects - 'By means of the free consent of its subjects, [the prince] has to obtain the obedience that it could neither attain nor maintain by force alone' (Althusser 2006 p.285). Thus, the association between subjection-subjectivity and the constitution of the dominant ideology is not arbitrary. The class struggle and the existing contradictions, invested with ideologies and social practices, and giving rise to their resolution and unification in the form of the dominant ideology, are as much the products as the producers of subjectivity. The subject, which can never be subsumed under the political, is produced from and within social antagonism. It is the strength of Althusser's analysis to have theorised simultaneously the displacement of the subject and its embeddedness in the antagonistic relations.

Althusser does not develop a theory of the legal subject, nor does he explicitly articulate concepts that would explain the function of subjective rights within the modern nation state. However, we may propose some tentative connections between his theoretical constructs, as we have interpreted them, and legal subjectivity. In the first place, the role of ideology in producing subjects extends a correlative function to law: in short, there is no room for law to exist outside of its ideological uses. That subjective rights are conceived, and become juridically meaningful, only within the rubric of public law, the law of the state, entails that rights are themselves in the service of the state-machine with its participation in the class struggle. This is not to say that subjective rights work homogenously or uni-directionally. From the perspective of the state as a 'class state', it could be said that rights form part of the legal codification of the interests of property owners- it is an expression of the bourgeoisie and of its power to appropriate individual freedom and the market, and protect its prerogatives' (Negri 2008, p. 111). However, from the more generalised perspective of the state as a separate and special body whose sole concern is the production of legal power, rights can be seen as the effects of the encounter between the state apparatus and concrete reality, that which is produced from the transformation of violence, in effect, the transmutation of social antagonism. It would then be the result of a creative, productive 
process, and, above all, a practical process, by which the hegemony of the dominant class is reified, which is to say that the class origins of its power are repressed or neutralised. If we were to read Althusser's notion of legal power sympathetically with Foucault's analytics of power, we might suggest that at stake in this transformation are the power relations that Foucault refers to as microphysical: those multiple and diffuse relations (normalising and disciplinary, but also constitutive and individualising) that inhabit the social field, ${ }^{17}$ penetrating and circulating within the social fabric in strategic ways, irreducible to the monolithic exercise of force or violence inherent to the juridical form of the state. Speaking within the discourse that takes war as the paradigm for an analysis of power, the subject that asserts a right is concerned with a singular right (his right, derived from the relationship of conquest, domination or seniority), and declares a strategic, perspectival truth, whereas 'universal truth and general right are illusions or traps' (Foucault 2003, p. 269). The legal and political subject is formed through power relations that are depersonalised (neither 'sovereign' nor 'governed' are essential categories) and exercised to give effect to a certain mode of governmental rationality. Ultimately, the mechanisms of subjection and the economic processes of reproduction belong to the same economy of power; the individual body as labour power is both a productive force and a subjected body. ${ }^{18}$ Similarly, we could find in Althusser a co-extensive relationship between the productive power of law (in maintaining the reproduction of the relations of production) and the subject that is produced through ideological interpellation. The legal subject that emerges, in one sense, is defined by that process of interpellation, with all its inherent limitations, but in another, actively represents the constitution of legal power reflective of the violence of social antagonism - this would be the space of his singular right and strategic truth.

In the second place, Althusser's critique of the state through the prism of aleatory materialism radically alters the stakes of political subjectification. As with the contingent economic and security imperatives which, for Foucault, marked a shift in the political technologies of government, the problem of constituting political authority is bound up with the singularity of events that render a national, unified government both fortuitous and possible; that is to say, the birth of the conditions for the enduring state reflects the emergence of the necessary from the contingent. The conjuncture and facticity inherent to the encounter projects a new emphasis on the concern with the reproduction of the mode of production, in the sense of an overriding materialism to the reproduction of social practices - for example, the relations that govern the processes of capitalist production give form to certain social structures, which, in turn, produce other structures, but always as the products of chance encounters (thus, both causes and effects are marked by their aleatory nature). 'For the aleatory materialist, all structural relations have both a history and a need for continuous reproduction' (Hardy 3013, p. 25). While the process associated with the history of social structures and their changes is said to be lacking a transcendental subject per se, social relations themselves may be considered to produce forms of subjectivity. The relation of forces that constitutes a conjuncture, with its inhrerent tension and agonism, and the resulting possibility of change, gives presence to social subjectivity, 'that of a conflictual human group, that is, of a class

${ }^{17}$ It is worth bearing in mind, as a point of distinction,that for Foucault the social field is not defined by its contradictions. As Deleuze remarks, it is one of Foucault's great innovations in the theory of power 'that a society does not contradict itself, or hardly does so...it strategizes itself, it makes up strategies' (2007, p. 127).

18 'This political investment of the body is bound up, in accordance with complex reciprocal relations, with its economic use; it is largely as a force of production that the body is invested with relations of power and domination; but, on the other hand, its constitution as labour power is possible only if it is caught up in a system of subjection (in which need is also a political instrument meticulously prepared, calculated and used); the body becomes a useful force only if it is both a productive body and a subjected body' (Foucault 1979, pp. 25-26). 
and therefore of antagonistic classes' (Althusser 1997b, p. 7). This form of subjectivity would not merely reflect the conflictual system of the relation of forces, it would give structure to their coincidence and participate in the restructuring of the conjuncture as part of the continuous reproduction of relations. This is arguably one aspect of the political practice emerging from the confluence of necessity and contingency that can serve to transform the 'social' from its established conception to something other, a new moment. 


\section{References}

Althusser, Louis. 1971. Ideology and Ideological State Apparatuses. In Lenin and Philosophy (trans: Ben Brewster) New York: Monthly review Press.

Althusser, Louis. 1997a. The Spectre of Hegel: Early Writings (trans: G. M. Goshgarian) London: Verso.

Althusser, Louis. 1997b. The Only Materialist Tradition, Part I: Spinoza (trans. T. Stolze). In The New Spinoza, ed. W. Montag and T. Stolze. Minneapolis: University of Minnesota Press.

Althusser, Louis. 2000. Machiavelli and Us (trans: Gregory Elliot) London: Verso.

Althusser, Louis. 2005. For Marx (trans: Ben Brewster) London: Verso.

Althusser, Louis. 2006. Philosophy of the Encounter: Later Writings, 1978-1987, ed. Francois Matheron and Oliver Corpet (trans: G. M. Goshgarian) London: Verso.

Althusser, Louis and Étienne Balibar. 2009. Reading Capital (trans: Ben Brewster) London: Verso.

Balibar, Étienne. 1993. The Non-Contemporaneity of Althusser. In The Althusserian Legacy, ed. E. Ann Kaplan and Michael Sprinker. London: Verso.

Deleuze, Gilles. 1991. The Fold. Yale French Studies 80: 227-247.

Deleuze, Gilles. 1992. Foucault (trans: Seàn Hand) Minneapolis: University of Minnesota Press.

Deleuze, Gilles. 2007. Two Regimes of Madness: Texts and Interviews 1975-1995 (trans: Ames Hodges and Mike Taormina) New York: Semiotext(e).

Derrida, Jacques. 1981. Positions (trans: Alan Bass) Chicago: University of Chicago Press.

Derrida, Jacques. 1993. Politics and Friendship: An Interview with Jacques Derrida. In The Althusserian Legacy, ed. E. Ann Kaplan and Michael Sprinker. London: Verso.

Derrida, Jacques. 1994. Specters of Marx (trans: Peggy Kamuf) New York and London: Routledge.

Ewald, François. 1992. A power without an exterior. In Michel Foucault: Philosopher (trans. Timothy J. Armstrong) New York: Harvester Wheatsheaf.

Foucault, Michel. 1972. The Archaeology of Knowledge and the Discourse on Language (trans: A. M. Sheridan Smith) New York: Pantheon Books. 
Foucault, Michel. 1977. Revolutionary Action: "Until Now”. In Language, Counter-Memory, Practice: Selected Essays and Interviews, ed. Donald F. Bouchard (trans: Donald F. Bouchard and Sherry Simon) Ithaca, New York: Cornell University Press.

Foucault, Michel. 1979. Discipline and Punish: The Birth of the Prison (trans: Alan Sheridan) New York: Vintage Books.

Foucault, Michel. 1997. The Politics of Truth, ed. Sylvère Lotringer and Lysa Hochroth. New York: Semiotext(e).

Foucault, Michel. 2001. Power: Essential Works of Foucault 1954-1984, vol. 3 (trans: Robert Hurley and others) London: Allen Lane, The Penguin Press.

Foucault, Michel. 2003. Society Must Be Defended: Lectures at the Collège De France, 1975-76, ed. Mauro Bertani and Alessandro Fontana; English series: Arnold I. Davidson (trans: David Macey) London: Allen Lane.

Foucault, Michel. 2009. Security, Population, Territory: Lectures at the Collège De France, 1977-1978, ed. Michel Senellart; English series: Arnold I. Davidson (trans: Graham Burchell) London: Pallgrave Macmillan.

Grant, John. 2005. Rethinking Althusser: Ideology, Dialectics, and Critical Social Theory. http://www.scribd.com/doc/49992337/Rethinking-Althusser-Ideology-Dialectics-and-Critical-Social-TheoryJohn-Grant. Accessed: 6 September 2012.

Hardy, Nick. 2013. Theory From the Conjuncture: Althusser's Aleatory Materialism and Machiavelli's dispositive. Décalages 1(3). http://scholar.oxy.edu/decalages/vol1/iss3/5.

Holden, Adam and Stuart Elden. 2005. 'It cannot be a Real Person, a Concrete Individual': Althusser and Foucault on Machiavelli’s Political Technique. Borderlands 4(2).

http://www.borderlands.net.au/vol4no2_2005/eldenhold_foucault.htm.

Kaplan, E. Ann, and Michael Sprinkler (eds). 1993. The Althusserian Legacy. London: Verso.

McGee, Kyle. 2012. Aleatory Materialism and Speculative Jurisprudence (I): From Abti-Humanism to NonHumanism. Law \& Critique 23: 141-162.

Močnik, Rastko. 1993. Ideology and Fantasy. In The Althusserian Legacy, ed. E. Ann Kaplan and Michael Sprinker. London: Verso.

Montag, Warren. 1995. "The Soul is the Prison of the Body": Althusser and Foucault, 1970-1975. Yale French Studies 88: 53-77. 
Montag, Warren. 2004. Politics: Transcendent or Immanent?: A response to Miguel Vatter's 'Machiavelli After Marx'. Theory and Event 7(4). http://muse.jhu.edu/journals/theory_and_event/v007/7.4vatter.html.

Morfino, Vittorio. 2005. An Althusserian Lexicon. Borderlands 4(2).

http://www.borderlands.net.au/vol4no2_2005/morfino_lexicon.htm.

Nancy, Jean-Luc. 2010. The Truth of Democracy (trans: Pascale-Anne Brault and Michael Naas) New York: Fordham University Press.

Negri, Antonio. 2008. The Porcelain Workshop: For a New Grammar of Politics (trans: Noura Wedell) Los Angeles: Semiotext(e).

Rancière, Jacques. 2011. Althusser's Lesson (trans: Emiliano Battista) London: Continuum.

Vatter, Miguel. 2004. Machiavelli After Marx: the Self-Overcoming of Marxism in the Late Althusser. Theory and Event 7(4). http://muse.jhu.edu/journals/theory_and_event/v007/7.4vatter.html. 